\title{
Grey mould on leaf mustard caused by Botrytis cinerea, a new disease in China
}

\author{
X. W. Xie ${ }^{1}$ - Z. X. Zhang ${ }^{1}$ A. L. Chai ${ }^{1}$ Y. X. Shi ${ }^{1} \cdot$ B. J. Li $^{1}$
}

Received: 18 August 2015 / Accepted: 19 June 2016 / Published online: 16 July 2016

(C) Australasian Plant Pathology Society Inc. 2016

\begin{abstract}
Leaf mustard (Brassica juncea) is a common vegetable widely distributed in China. From September to December, 2014, grey mould disease on leaf mustard was discovered and spread quickly with a high incidence of 35$70 \%$ in Shunyi District, Beijing, China. The pathogen was identified based on detailed morphological, cultural characteristics and pathogenicity testing. In addition, the DNA sequence for four gene regions ITS, G3PDH, HSP60 and RPB2 of our isolate were compared with those of some previously reported Botrytis cinerea and other similar species of the genus Botrytis. The results showed that Botrytis cinerea is the first record causing gray mould disease on leaf mustard in China.
\end{abstract}

Keywords Grey mould $\cdot$ Leaf mustard $\cdot$ New disease

Leaf mustard (Brassica juncea), an annual or biennial Cruciferae herbaceous plant, popular for its rich nutrients and medicinal value, is native to China. In China, especially in the south of Huaihe Qinling Mountains and the east of Tibet Plateau to the southeast of the coastal areas, leaf mustard is not only an important fresh vegetable but also a significant raw material for processing. For example, it can be processed into a pickled vegetable, which is very popular for its low cost, good taste and long shelf life. Botrytis cinerea is regarded as one of the most destructive plant pathogens and has a variety of modes of attack, diverse hosts as inoculum sources, and it

X. W. Xie and Z. X. Zhang contributed equally to this study.

B. J. Li

libaoju@caas.cn

1 Institute of Vegetables and Flowers, Chinese Academy of Agricultural Sciences, Beijing 100081, China can survive as mycelia and/or conidia or for extended periods as sclerotia in crop debris (Williamson et al. 2007). Botrytis cinerea has a worldwide distribution and occurs wherever host crops are grown (Jarvis 1977). The macroconidia of $B$. cinerea can be transported by wind over long distances (Staats et al. 2005).

During September to December 2014, some diseased leaf mustard plants were observed with typical symptoms of grey mould in Shunyi District, Beijing, China. Symptoms initially appeared as yellow lesions or V-shaped blights on the leaves (Fig. 1a). As the disease developed, brown blights turned dark brown and a thick, grey mass of mycelium and conidia occurred on infected leaves. Eleven diseased samples were collected, of which eight samples were isolated randomly (five tissues per sample). Necrotic tissues were cut into $3 \mathrm{~mm}^{2}$ per piece and surface disinfested in $75 \%$ ethanol for $30 \mathrm{~s}$, then rinsed with sterilised distilled water, plated on potato dextrose agar (PDA) and incubated at $26^{\circ} \mathrm{C}$ until a mass of mycelium grew out of infected tissues (this took about two days). A total of 38 colonies with the same characteristics were obtained. The colonies were transferred to PDA slants and incubated at $26{ }^{\circ} \mathrm{C}$ for seven days in the fungus library of Institute of Vegetables and Flowers, Chinese Academy of Agricultural Sciences as specimens for future reference.

Colonies on PDA at $26{ }^{\circ} \mathrm{C}$ were white to grey, reverse lighter, $52-73 \mathrm{~mm}$ in diameter after $7 \mathrm{~d}$-dark-culture (Fig. 1b). Small, irregular, hard and dark sclerotia were found on PDA discs within about 3 weeks (Fig. 1c). Conidiophores were about $13.2-22.4 \times 142.0-427.0 \mu \mathrm{m}$, brown to light brown, solitary or in clusters, branched and bearing obvious, enlarged conidiogenous cells, along with subglobose or clubshaped at the apices. Conidia were light brown to colourless, ellipsoid or globose, single-celled, smooth, usually 8.5 $16.9 \times 6.3-8.9 \mu \mathrm{m}$ (Fig. 1d). Morphological features of the fungus isolated in this research were similar to those 
Fig. 1 Typical symptoms of grey mould disease on naturally infected leaf mustard caused by Botrytis cinerea. a V-shaped blight on leaves. b Colony on PDA at $26^{\circ} \mathrm{C}$ after 5 days. c Sclerotia were found on the PDA discs after 3 weeks. d Microscopic structures of conidiophores and its conidia formed on 3-week-old PDA cultures $($ bar $=10 \mu \mathrm{m})$. Symptoms observed in pathogenicity test: e yellow lesions observed on leaves 5 days after inoculation. f Infected leaves had completely rotted 8 days after inoculation
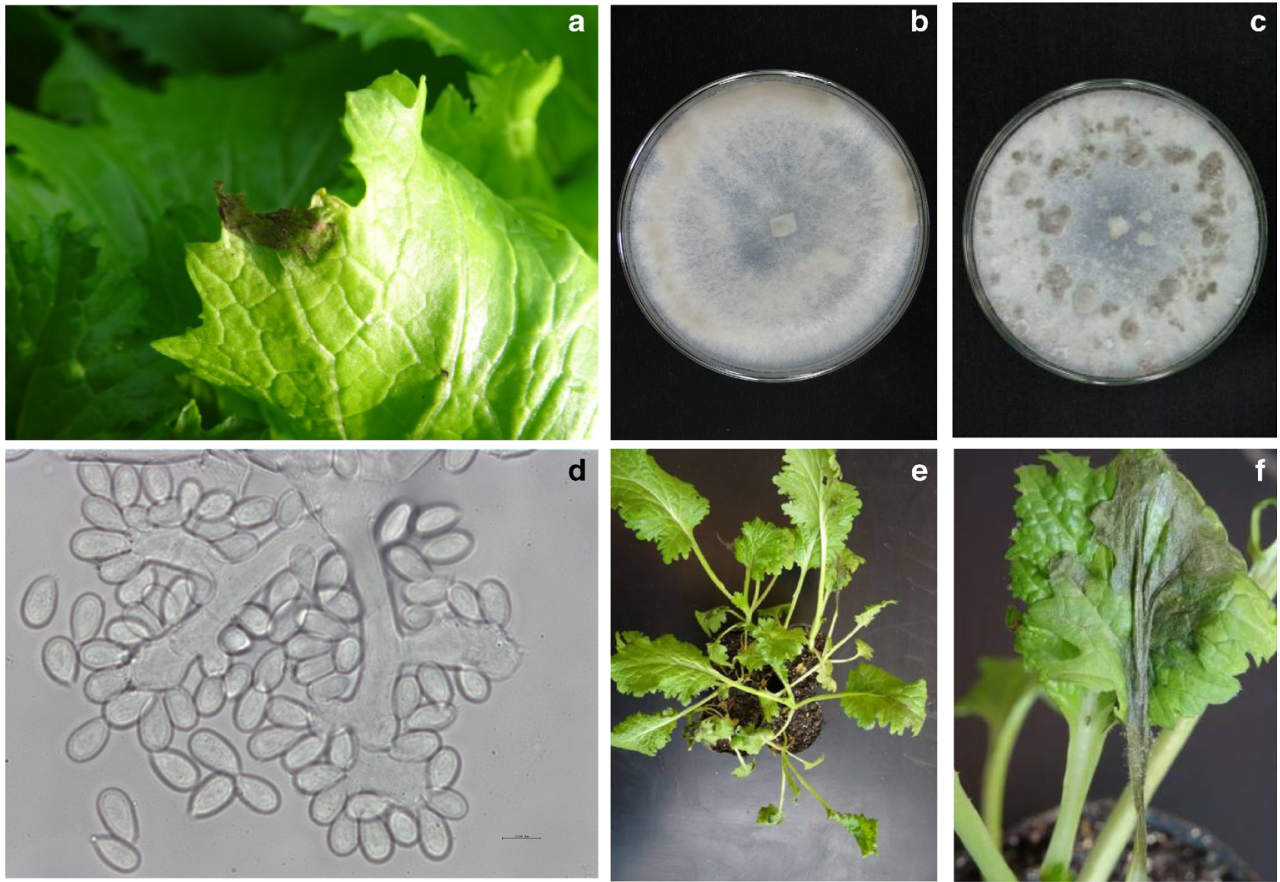

previously reported of Botrytis cinerea. (Ellis 1971; Barnett and Hunter Barry 1972; Zhang 2006; Lu et al. 2014).

The pathogenicity test was carried out on two-week-old potted plants of leaf mustard 'Xiangmanyuan'. Three replications (ten plants per replication) were randomly selected and the pathogenicity test was performed by using a spore suspension containing $10^{6}$ conidia per millilitre as inoculum. The spore suspension was prepared by adding $10 \mathrm{~mL}$ of sterilised water to a PDA disc (3 weeks old) and the conidia were dislodged with a brush. Control plants (three replication and ten plants per replication) were sprayed with sterilised water. Thus, 60 potted plants were used in the pathogenicity

Table 1 Region or gene and its primer sequence and PCR thermocycling pattern used in the study

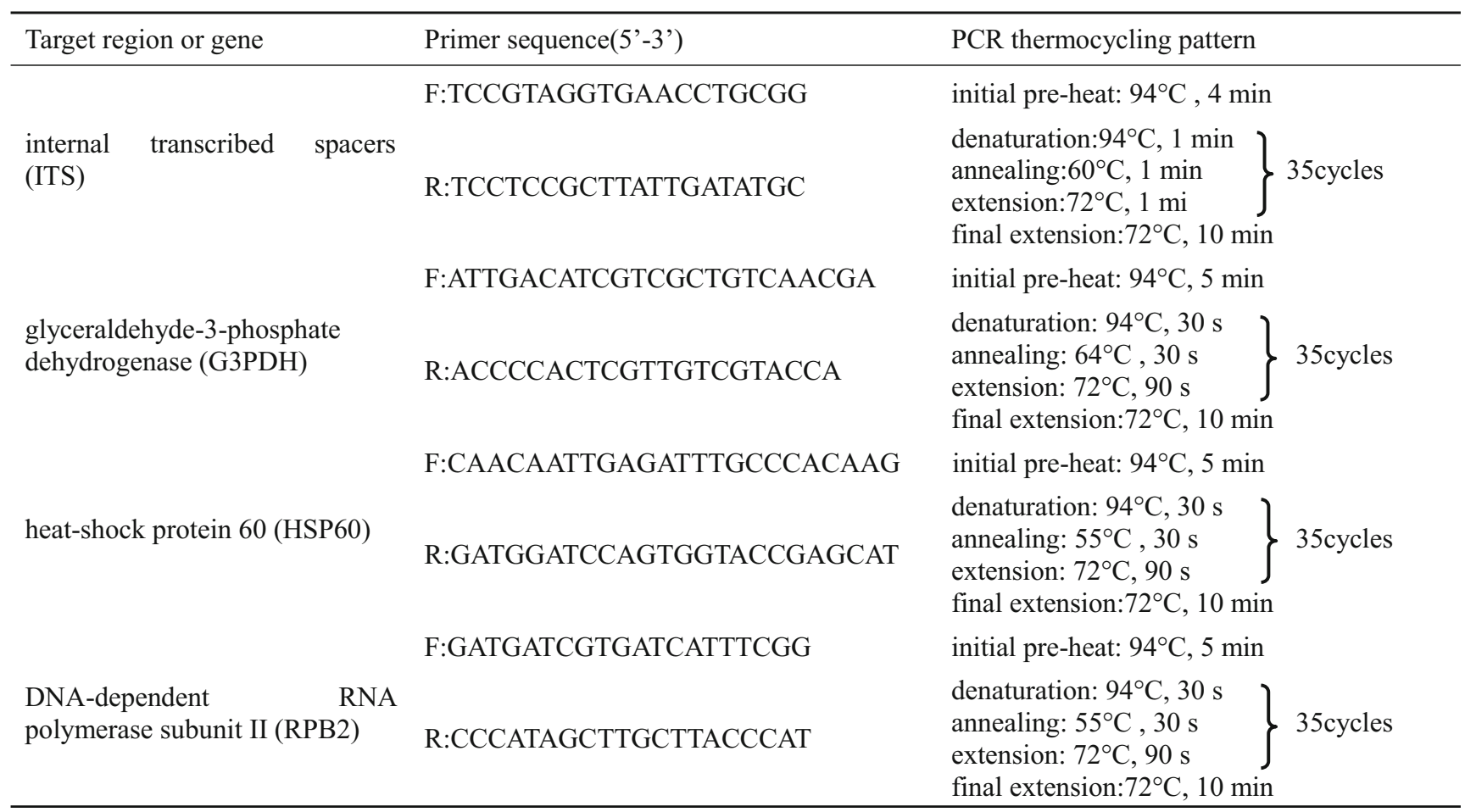


Fig. 2 Phylogenetic tree was constructed by the neighborjoining method using the MEGA 5.1 program according to the G3PDH sequence of Botrytis isolates and related species, including a new isolate from this study (in bold) and 14 isolates retrieved from GenBank. Bootstrap values resulting from 1000 replicates are shown at the branch points

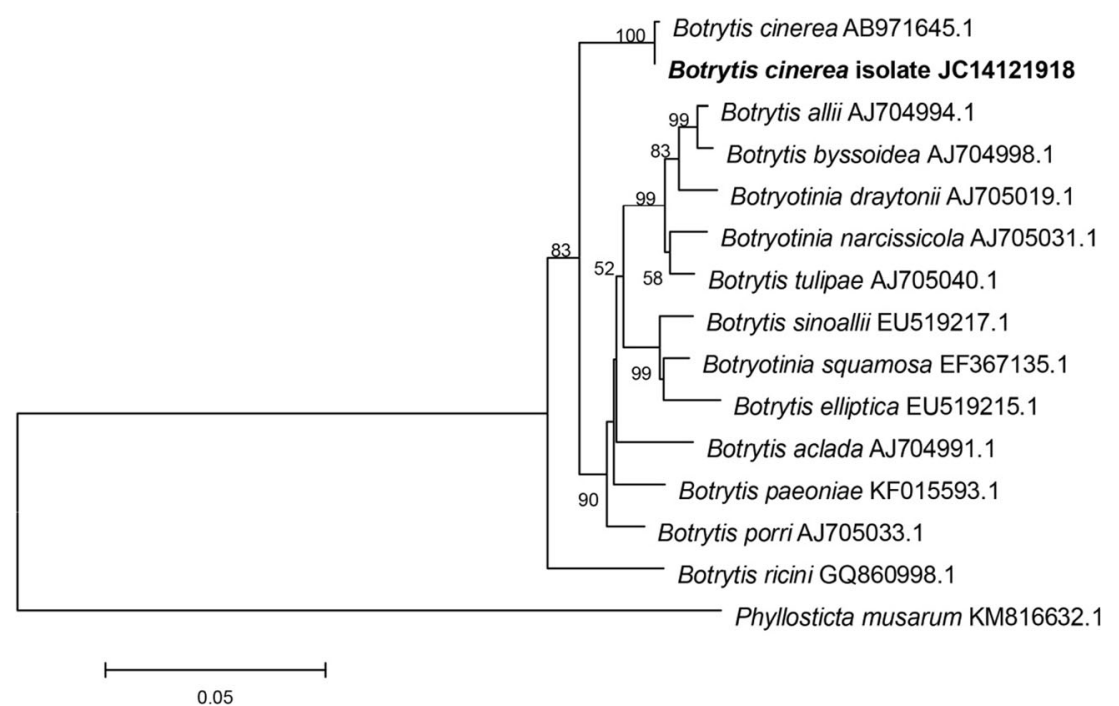

test in total. Plants were maintained in a humidity chamber for $48 \mathrm{~h}$ (temperature $25 \pm 0.5{ }^{\circ} \mathrm{C}$; RH $99 \%$; photoperiod $12 \mathrm{~h}$ ), then transferred to a greenhouse with regular management until the onset of symptoms. To verify Koch's postulates, the fungus was re-isolated from the diseased leaves and compared with the original one.

The total genomic DNA of isolate JC14121918 was extracted by the CTAB method after the mycelial tissue was harvested and ground into a powder (submerged in liquid nitrogen). DNA amplification was performed by polymerase chain reaction (PCR). The internal transcribed spacers (ITS), glyceraldehyde-3-phosphate dehydrogenase (G3PDH), heatshock protein 60 (HSP60) and DNA-dependent RNA polymerase subunit II (RPB2) genes were amplified using primer pairs ITS1 (White et al. 1990), G3PDH (Maeda et al. 2010), HSP60 and RPB2 (Staats et al. 2005) respectively. The primer sequences and polymerase chain reaction (PCR) thermocycling patterns are listed in Table 1. The amplicons of ITS-5.8S rDNA, G3PDH, HSP60 and RPB2 genes were sequenced and put in the GenBank database of NCBI to blast, of which the G3PDH sequences obtained were used to edit and align with the downloaded G3PDH sequences of Botrytis using the MEGA 5.1 software package (Tamura et al. 2011). Phylogenetic analysis was conducted with the NeighbourJoining (NJ) method (Saitou and Nei 1987).

The sizes of the amplified ITS, G3PDH, HSP60 and RPB2 genes were 543, 938, 1071 and 1185 bp respectively, and their GenBank Accession Nos. were KT006154, KT006155, KT006156 and KT006157 respectively. Sequence analysis of the amplicons showed 99-100\% identity with those of Botrytis cinerea (GenBank Accession Nos. KF533020.1, KF857463.1, CP009811.1 and CP009818.1 respectively).

Table 2 Isolates used in the phylogeny study and its information, including 13 Botrytis. spp. and an outgroup sequence (Phyllosticta musarum)

\begin{tabular}{llll}
\hline Species & strain & Origin & GenBank number (G3PDH) \\
\hline Botrytis cinerea & JC14121918 & China & KT006155 \\
Botrytis allii & MUCL1150 & Norway & AJ704994 \\
Botrytis ricini & - & - & GQ860998.1 \\
Botrytis porri & MUCL3349b & Belgium & AJ705033.1 \\
Botrytis paeoniae & IBx12-Pi & Chile & KF015593.1 \\
Botrytis aclada & MUCL3106 & USA & AJ704991 \\
Botrytis elliptica & lilyBC-2 & China & EU519215.1 \\
Botrytis squamosa & 2023 & Canada & EF367135 \\
Botrytis sinoallii & OnionBC-23 & China & EU519217.1 \\
Botrytis narcissicola & CBS287.38 & UK & AJ705031 \\
Botrytis tulipea & BT9001 & The Netherlands & AJ705040.1 \\
Botrytis draytonii & 9701 & - & AJ705019 \\
Botrytis byssoidea & MUCL94 & USA & AJ704998.1 \\
Phyllosticta musarum & GZAAS6.1228 & Thailand & KM816632.1 \\
\hline
\end{tabular}


Phylogenetic analysis showed that our isolate was clustered in the same group with Botrytis cinerea and explicitly distinguished from other Botrytis spp. (Fig. 2), proving that the isolate was $B$. cinerea. Details of the strains used in the phylogeny study are listed in Table 2.

Typical symptoms of yellow lesions were observed on leaves 5 days after inoculation (Fig. 1e), and the diseased leaves completely rotten 8 days after inoculation (Fig. 1f), which is similar to those observed on leaf mustard plants under agricultural field conditions. The control plants showed no symptoms of damage. The morphological and cultural characteristics of strains re-isolated from the inoculated plants were the same as the original strains which were isolated from naturally diseased leaf mustard leaves.

Wubben et al. (1999) reported that during all stages of infection, B. cinerea produces a spectrum of cell-walldegrading enzymes, which might be involved in pathogenesis. Grey mould disease caused by $B$. cinerea has been reported previously on many hosts of Cruciferae, such as Brassica campestris, B. napus, B. oleracea, B. pekinensis, B. rapa (http://nt.ars-grin.gov/fungaldatabases/). In this study, the pathogen causing disease on field leaf mustard plants was identified as Botrytis cinerea based on the morphological features, pathogenicity test and molecular identification. It is the first report of Botrytis cinerea infecting leaf mustard in China.

Acknowledgments This work was supported by the Special Fund for Agroscientific Research in the Public Interest of the People's Republic of China (grant no. 201303025), the Science and Technology Innovation Program of the Chinese Academy of Agricultural Sciences (CAASASTIP-IVFCAAS) and the Key Laboratory of Biology and Genetic Improvement of Horticultural Crops, Ministry of Agriculture, P. R. China.

\section{References}

Barnett HL, Hunter Barry B (1972) Illustrated genera of imperfect fungi. Burgess Publishing Company, Minneapolis (MN)

Ellis MB (1971) Dematiaceous Hyphomycetes. Commonwealth Mycological Institute, Kew (England)

Jarvis WR (1977) Botryotinia and Botrytis species; taxonomy, physiology and pathogenicity. Monograph No. 15. Canadian Department of Agriculture, Ottawa

Lu BH, Yang L, Wu XY, Gao J (2014) First report of Botrytis cinerea causing stem blight of Scutellaria baicalensis in Jilin Province, China. Plant Dis 98:1430-1430

Maeda K, Kurahashi Y, Ohsato S, Yoneyama K (2010) Appearance of a new leaf rot disease on common ice plant. J Gen Plant Pathol 76: 303-309

Saitou N, Nei M (1987) The neighbor-joining method: a new method for reconstructing phylogenetic trees. Mol Biol 4: 406-425

Staats M, Van Baarlen P, Van Kan Jan AL (2005) Molecular phylogeny of the plant pathogenic genus Botrytis and the evolution of host specificity. Mol Biol Evol 22:333-346

Tamura K, Peterson D, Peterson N, Stecher G, Nei M, Kumar S (2011) MEGA5: molecular evolutionary genetics analysis using maximum likelihood, evolutionary distance, and maximum parsimony methods. Mol Biol Evol 28:2731-2739

White TJ, Bruns T, Lee S (1990) Amplification and direct sequencing of fungal ribosomal RNA genes for phylogenetics. In: Innis MA, Gelfand DH, Sninsky TJ, White TJ (eds) PCR protocols: a guide to methods and applications. CABI, New York (NY), pp. 315-322

Williamson B, Tudzynski B, Tudzynski P, Van Kan Jan AL (2007) Botrytis cinerea: the cause of grey mould disease. Mol Plant Pathol 8:561-580

Wubben JP, Mulder W, Have Ten A, Van Kan Jan AL, Visser J (1999) Cloning and partial characterization of Endopolygalacturonase genes from Botrytis cinerea. Appl Environ Microbiol 65:1596-1602

Zhang ZY (2006) Flora Fungorum Sinicorum. Vol. 26. Botrytis, Ramularia. Science Press, Beijing, p. 277 